Tomcsik, J. \& Guex-Holzer, S. (1954). J. gen. Microbiol. 10, 97-109

\title{
Demonstration of the Bacterial Capsule by means of a pH-dependent, Salt-like Combination with Proteins
}

\author{
BY J. TOMCSIK AND S. GUEX-HOLZER \\ Institute for Hygiene and Bacteriology, University of Basel, Switzerland
}

SUMMARY: The capsules of bacteria and of Cryptococcus neoformans are invisible under the phase-contrast microscope. They can be made visible through addition of a number of proteins at a certain, usually very narrow, $\mathrm{pH}$ range lying on the acid side of the isoelectric point of the proteins. The $\mathrm{pH}$ range at which the reaction occurs shifts with the isoelectric point of the protein used. The optimal $\mathrm{pH}$ range depends, on the other hand, upon the capsular substance of the micro-organism. The non-specific capsular reaction is elicited through a salt-like combination of several proteins with the bacterial capsule, leading to precipitation at a $\mathrm{pH}$ value on the alkaline side of the isoelectric point of the bacterial surface and on the acid side of the isoelectric point of the proteins. The reaction is reversible; it disappears on changing the $\mathrm{pH}$. The non-specific capsular reaction at an inter-isoelectric $\mathbf{p H}$ zone of the bacterial surface and of the proteins is not a 'swelling' reaction. A swelling of the capsule might occur with some bacteria as a secondary phenomenon on the alkaline side of the reaction zone. The reaction occurs in a broader zone in members of the genus Bacillus where it reveals a distinct shrinkage of the capsule at the acid side of the reacting zone.

Nakamura (1923) studied the effect of acids and alkalis on the egg-white lysis of sarcina. He observed that $\mathrm{HCl}$ at $\mathrm{N} / 200$ to $\mathrm{N} / 1600$ prevented the lysozyme activity. When, however, an hour later the suspension was made slightly alkaline with $0.05 \mathrm{~N}-\mathrm{NaOH}$, an instantaneous lysis occurred. When studying the effect of lysozyme on the cell structure of capsulated lysozymesensitive members of the genus Bacillus (Tomesik \& Guex-Holzer, 1952), we repeated the experiment of Nakamura and extended his observation by examining bacteria, after the addition of egg-white at different $\mathrm{pH}$ values, under the phase-contrast microscope. During this experiment, we made the unexpected observation that the capsule of these bacteria was beautifully demonstrated in the presence of a 1/50 dilution of egg-white at about s/320-HCl. The fractionation of egg-white revealed that the albumin, globulin and lysozyme fractions all were able to induce a non-specific capsular reaction; however, the optimal $\mathrm{pH}$ zone for eliciting this reaction was different with the three different proteins. The purpose of this paper is to describe this phenomenon and to study the behaviour of a representative member of capsulated microorganisms towards several proteins, including proteins with different isoelectric points.

\section{MATERIALS AND METHODS}

Organisms. Bacillus anthracis: strain Vollum (NCTC 7200); an attenuated strain $\left(\mathbf{A}_{2}\right)$ isolated by us from a Pasteur vaccine. A strain of $\boldsymbol{B}$. megaterium, which produced a capsule on ordinary agar medium, obtained through the kindness of J. P. Aubert (Service de Fermentations, Institut Pasteur, Paris). 
Bacillus $M$. isolated and described by us (Tomcsik, 1950; Tomcsik \& Guex, 1951). A strain of B. subtilis which produced a capsule in $3 \mathrm{hr}$. agar cultures and abundant slime which consisted of D-glutamic acid polypeptide (strain studied by Tomesik \& Guex, 1951). A strain of Streptococcus haemolyticus, group C (human), isolated from a case of otitis media (obtained from A. Grumbach, Hygiene Institute, University of Zürich). Strains of Klebsiella pneumoniae, types A, B and C (from the Statens Seruminstitut, Copenhagen) and another type $B$ isolated in our Institute from a guinea-pig epidemic. Diplococcus pneumoniae, type III, a strain isolated in our laboratory from a human case of pneumonia. Cryptococcus neoformans, strains D.U. and R.E. (obtained from Dr E. W. Evans, Department of Bacteriology, University of Michigan, Ann Arbor, U.S.A.).

Culture media. Gladstone \& Fildes (1940) CCY agar medium was used throughout the work with the following exceptions: the capsule production of the B. anthracis strains was not optimal on CCY medium in presence of $20 \%(\mathrm{v} / \mathrm{v}) \mathrm{CO}_{2}$; thus Difco peptone agar was used for this purpose. The streptococcus and pneumococcus were grown on blood agar and Cryptococcus neoformans on Sabouraud medium. B. subtilis, B. megaterium and Bacillus $\boldsymbol{M}$. were incubated at $32^{\circ}$, all the other strains at $37^{\circ}$.

Proteins. Albumin and globulin fractions of horse serum as well as those of egg-white were prepared by ammonium sulphate fractionation (Sahyun, 1944). Crystallized lysozyme was prepared according to the method of Alderton \& Fevold (1946); this preparation was compared with a sample obtained from the Mann Research Laboratories, New York. The other preparations were as follows: pepsin and trypsin (Kahlbaum); isoelectric casein (Difco); haemoglobin and protaminsulphate (Hoffmann La Roche, Basel); bovine plasma albumin fraction V (Armour Laboratories, London).

Preparation of the reacting mixture of bacteria and proteins at different $\mathrm{pH}$ values. The bacteria were usually suspensions in $0.85 \% \mathrm{NaCl}$ from $24 \mathrm{hr}$. agar cultures. The turbidity was less than in tube no. 3 of the McFarland $\mathrm{BaSO}_{4}$ standard series (Kolmer, 1924), giving ten or more bacteria in the reacting mixture per field in microscope preparations with the oil-immersion objective no. 90 and ocular no. 10. Different dilutions of the proteins in physiological salt solution or in distilled water were added to equal volumes of bacterial suspension; $0.3 \mathrm{ml}$. of this mixture was added to $0.3 \mathrm{ml}$. of different buffer solutions which covered a $\mathrm{pH}$ range between 2 and 9 at intervals of $0.4 \mathrm{pH}$ unit up to $\mathrm{pH} \mathbf{4} \cdot \mathbf{4}$, and at larger intervals on the more alkaline side of the series. The buffer solutions of Teorell \& Stenhagen (1938) were used throughout, if not otherwise mentioned. Two loopfuls of these mixtures placed on slides were examined under cover-glasses with the oilimmersion objective of the phase-contrast microscope of Wild and Co. (Heerbrugg, Switzerland). The microscopic examinations could be carried out immediately after setting up the series, but the results were hardly changed when the series was kept at room temperature for $20 \mathrm{hr}$. The microscopic examinations were usually carried out $1 \mathrm{hr}$. after setting up the series. The photographs were made with Leitz Ortholux microscope and Aristophot 
microphotographic apparatus, using the phase-contrast condenser and objectives of Wild and Co.

The same results were obtained by using, instead of buffer solutions, appropriate distilled water dilutions of $\mathrm{N}-\mathrm{HCl}$ or of $\mathrm{N}$-acetic acid covering the same $\mathrm{pH}$ range. An even distribution of $\mathrm{pH}$ differences, taking into consideration the buffering actions of proteins, could, however, not be achieved with the latter method.

Typical examples of the buffer series are given in the Tables 1-3. It should be pointed out that at the protein concentrations used in Tables 2 and 3 $(0.05 \%, \mathrm{w} / \mathrm{v})$ the actual $\mathrm{pH}$ value was about 0.4 unit higher than the $\mathrm{pH}$ of the buffer solutions, at least in the range $\mathbf{p H} 2-4$. Electrometric determinations were carried out only in certain selected series. The reacting mixtures were prepared for this purpose in the same proportions as above, using, however, 20 times larger volumes of each of the reagents. The electrometric $\mathrm{pH}$ determinations are summarized in the Table 4.

\section{RESULTS}

Strains of eight species of capsulated micro-organisms, including three serological types of Klebsiella, were studied as regards their behaviour towards twelve proteins at different $\mathrm{pH}$ values. The proteins had to be studied at different concentrations; thus it was necessary to carry out the microscopical examination of several hundred series. In consequence only the essential results, illustrating certain principles, can be described.

\section{Non-specific capsular reaction of different micro-organisms}

The capsulated micro-organisms studied can be divided on the basis of the chemical nature of their capsule into three groups; organisms of the first group produce polysaccharide; those of the second group a polypeptide capsule; the capsule of the third group is of complex nature containing both polysaccharides and polypeptides. The pneumococci, the klebsiellas and the streptococci belong to the first group, with capsules of generally known chemical compositions. The capsules of these micro-organisms are classified by Stacey (1946) as mucopolysaccharides, and the majority of them contain uronic acids.

Table 1 shows the non-specific capsular reaction with bovine serum diluted 1/20. The $\mathrm{pH}$ value of the reaction mixture containing, for instance, buffer solution of $\mathrm{pH} 2 \cdot 8$, corresponds to $\mathrm{pH} 4$ owing to the strong buffering action of the serum at this concentration. The capsular reaction of the klebsiellas (Pl. 2, fig. 17) and the streptococci occurred at $\mathrm{pH} 4$ and $4 \cdot 4$ respectively, extending only with the klebsiella types $A$ and $C$, up to $4 \cdot 8$. Both klebsiella type B strains showed a definitely lower optimum. The same observation was made with horse and human sera and with a number of other proteins which reacted with the capsule. Other strains must be studied in order to establish whether this difference can really be correlated with the chemical nature of the type B klebsiella polysaccharide. The size of the capsule was not 
larger at the optimal reaction than that found by the indian ink method. Only in preparations kept in a wet chamber for several hours could a secondary swelling occasionally be observed. The only pneumococcus strain studied gave the optimal reaction at a still higher $\mathrm{pH}$ value than did the klebsiellas of types $\mathbf{A}$ and $\mathbf{C}$. A swelling of the capsule was observed regularly only with this organism (Pl. 2, fig. 18).

Table 1. Non-specific $\mathrm{pH}-$ dependent capsular reaction of several bacteria with bovine serum diluted $1 / 20$

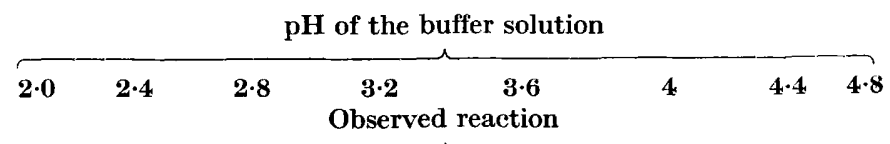

Organism

Cryptococcus neoformans

Klebsiella pneumoniae type B

K. pneumoniae type A, C

Streptococcus haemolyticus group C

Diplococcus pneumoniae type III

Bacillus subtilis

B. anthracis, 'Vollum'

B. anthracis (vaccine)

B. megaterium

Bacillus $M$

\begin{tabular}{ccccccccc}
\hline+ & +++ & +++ & - & - & - & - & - \\
- & ++ & ++ & \pm & - & - & - & - \\
$(+)$ & $(+)$ & ++ & +++ & +++ & - & - & - \\
- & \pm & + & + & \pm & - & - & - \\
- & - & \pm & + & +++ & +++ & - & - \\
- & - & + & ++ & +++ & + & - & - \\
$( \pm)$ & $( \pm)$ & $(+)$ & $(+++)$ & ++++ & +++ & + & - \\
$( \pm)$ & $(+)$ & $(+)$ & $(+++)$ & ++++ & +++ & + & - \\
$( \pm)$ & $( \pm)$ & $(+)$ & $(++)$ & +++ & +++ & ++ & - \\
$( \pm)$ & $(+)$ & $(++)$ & ++ & +++ & ++++ & + & -
\end{tabular}

++++ denotes the maximal reaction, the capsule appearing in the phase-contrast microscope as a dark, grey body.

+ denotes a very faint grey capsule.

++ and +++ denote grades between + and ++++ .

\pm denotes the appearance of a faint grey capsule only on some bacteria.

( ) denotes shrinkage of the capsule and increased light scattering of the bacterial bodies.

The chemical nature of the capsular substance of $C$. neoformans was determined by Drouhet, Segretain \& Aubert (1950), by Evans \& Mehl (1951) and by Evans \& Theriault (1953); xylose, mannose and glucuronic acid were found in the purified capsular polysaccharide. C. neoformans showed in our studies the lowest $\mathrm{pH}$ zone as compared with any other capsulated microorganisms, with each of the proteins tested. No swelling of the capsule was observed at the optimal pH. Neill, Castillo, Smith \& Kapros (1949) also did not observe swelling, when studying the specific capsular reaction of this micro-organism by the Neufeld test. On the contrary, a definite contraction of the capsule was observed, with our method, on the acid side of the reacting pH zone.

In the second group of bacteria, those which produce polypeptide capsules, $B$. anthracis and $B$. subtilis could be separated. Capsular substance of B. anthracis was separated from the bacterial polysaccharide by Tomesik \& Szongott (1933); Bodon \& Tomesik (1934) demonstrated that only the polypeptide and not the polysaccharide antibody gives a specific reaction with the capsule of $\boldsymbol{B}$. anthracis. The chemical nature of this capsular substance was cleared up by Ivanovics \& Bruckner (1937) who showed that it is a D-glutamic acid polypeptide; these observations were confirmed and extended by Hanby 
\& Rydon (1946), Hanby, Waley \& Watson (1948), Ambrose \& Hanby (1949), Housewright \& Thorne (1950). Ivanovies \& Erdös (1937) isolated the same substance from $B$. subtilis. In the case of $B$. anthracis grown on agar medium with $20 \%(\mathrm{v} / \mathrm{v})$ atmospheric $\mathrm{CO}_{2}$ concentration, the non-specific capsular reaction is easily demonstrable with all sera and proteins over a broad zone of $\mathrm{pH}$ values (Pl. 1, figs. 2, 3, 5). On the more acid side of this zone (see Table 1) a definite contraction of the capsule was observed (Pl. 1, fig. 6). The bacteria and the contracted capsules showed a peculiar light-scattering which made photography difficult.

Our $B$. subtilis strain had to be incubated only a few hours at $32^{\circ}$ in order to show a considerable proportion of capsulated bacilli (Pl. 1, fig. 10). In older cultures the polypeptide is given off as a slimy substance. The $\mathrm{pH}$ zone of the non-specific capsular reaction was narrower than with $B$. anthracis and the contracted capsules at acid reaction were hardly visible. A slime reaction, analogous to the non-specific capsular reaction, can be demonstrated occasionally by increasing the concentration of protein. In these cases the $\mathrm{pH}$ range at which the capsular and the slime reactions can be demonstrated is the same.

We listed in the third group of capsulated bacteria B. megaterium and Bacillus $M$ which have a complex capsular composition. As shown in recent studies (Tomesik, 1951; Tomcsik \& Guex-Holzer, 1951, 1952), the polypeptide antibody produced by intravenous injections of killed capsulated $\boldsymbol{B}$. anthracis organisms into rabbits reveals a homogeneously distributed capsular substance in these bacteria (Pl. 2, fig. 14). On the other hand, the homologous specific antibodies, which can be specifically absorbed with the serologically distinct polysaccharides of these two bacteria, induce the visibility of a characteristic capsular structure (Pl. 2, fig. 15), as well as of the cell wall (Tomcsik \& Guex-Holzer, 1952). The analysis of these polysaccharides will be reported in another communication. It is, however, interesting in view of the present work that these polysaccharides do not contain uronic acids. The reaction of these bacilli with proteins, that is to say, the non-specific capsular reaction, occurred practically at the same $\mathrm{pH}$ range as with the $B$. anthracis strains. The shrinking of the capsule and the light scattering of these bacilli is very pronounced on the more acid side of the reacting zone. In comparing microphotographs, figs. 14 and 15 of Pl. 2, showing the specific capsular reactions with the polypeptide and with the polysaccharide substances of the capsules, with the microphotographs, figs. 11 to 13 of $\mathrm{Pl}$. 2, on the non-specific capsular reactions with proteins, the similarity with the polypeptide reaction is apparent. Later in this paper it will be shown that a purified polysaccharide isolated from these bacteria does not give a precipitation reaction with proteins at an appropriate $\mathrm{pH}$ range as the polypeptide does.

\section{Effect of different proteins on the non-specific capsular reaction}

The $\mathrm{pH}$ zones in which the non-specific capsular reaction occurs with bovine serum remain essentially the same when horse or human serum is used. Human serum has an advantage inasmuch as precipitation and agglutination, which 
disturbs the microscopic examination of $B$. anthracis, occurs to a lesser degree. $C$. neoformans showed the optimal non-specific capsular reaction with each of these sera at more acid reactions, $B$. anthracis and related bacilli at less acid reaction. The reacting $\mathrm{pH}$ zones of the other bacteria covered a range between these two extremes. The zones may shift on using different proteins, but their sequence regarding the different micro-organisms remains unchanged. In consequence only the reactions of $\boldsymbol{C}$. neoformans and B. anthracis are summarized in the Tables 2 and $\mathbf{3 .}$

Table 2. Non-specific $\mathrm{pH}-$ dependent capsular reaction of Cryptococcus neoformans with different proteins

pH value of buffer solution used

$\begin{array}{lllllllllll}2 \cdot 0 & 2 \cdot 4 & 2 \cdot 8 & 3 \cdot 2 & \begin{array}{c}3 \cdot 6 \\ \text { Reaction observed }\end{array} & 4 \cdot 4 & 5 & 6 & 7 & 8 & 9\end{array}$

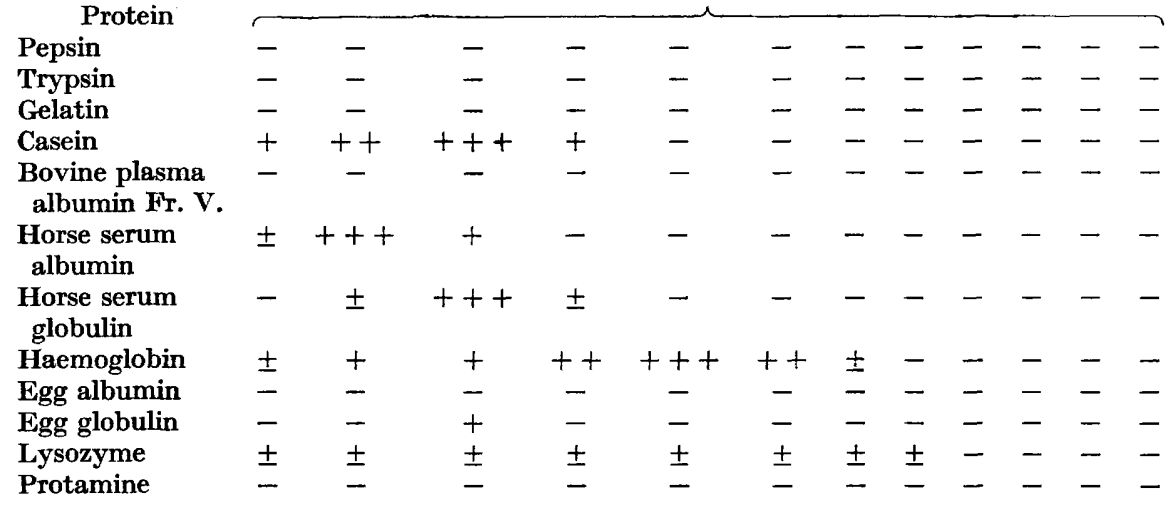

Symbols as Table 1.

Table 3. Non-specific $\mathrm{pH}-$ dependent capsular reaction of Bacillus anthracis with different proteins

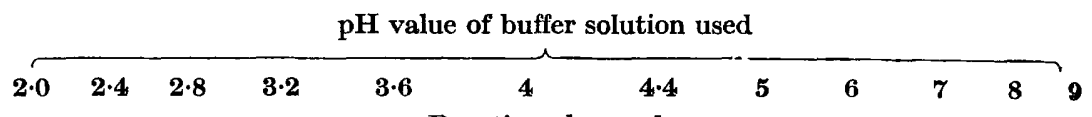

Protein

Pepsin

Trypsin

Gelatin

Casein

Bovine plasma

albumin Fr. V.

Horse serum

albumin

Horse serum

globulin

Haemoglobin

Egg albumin

Egg globulin

Lysozyme

Protamine

$\begin{array}{cccccc}- & - & - & - & - & - \\ - & - & - & - & - & - \\ - & ( \pm) & ( \pm) & ( \pm) & + & \pm \\ ( \pm) & ( \pm) & (+) & (+) & ++ & +++ \\ ( \pm) & ( \pm) & (+) & (+) & + & \pm \\ \pm) & ( \pm) & (+) & (++) & +++ & +++ \\ ( \pm) & ( \pm) & (+) & (++) & +++ & ++++ \\ (+) & (+) & (+) & (+) & (++) & ++ \\ ( \pm) & ( \pm) & (+) & (+) & + & \pm \\ ( \pm) & ( \pm) & (+) & (+) & + & \pm \\ - & - & ( \pm) & ( \pm) & (+) & (+) \\ \pm & \pm & \pm & \pm & \pm & \pm\end{array}$

Symbols as Table 1 .

$\begin{array}{cccccc}- & & - & - & - & - \\ - & - & - & - & - & - \\ - & - & - & - & - & - \\ + & - & - & - & - & - \\ - & - & - & - & - & - \\ - & - & - & - & - & - \\ + & - & - & - & - & - \\ ++ & + & - & - & - & - \\ - & - & - & - & - & - \\ - & - & - & - & - & - \\ (+) & + & ++ & ++ & - & - \\ \pm & \pm & \pm & \pm & \pm & \pm\end{array}$ 
The concentration of proteins used in the Tables 2 and 3 was $0.05 \%(w / v)$. With some of the proteins, as for example casein and haemoglobin, $0.005 \%$ $(w / v)$ may elicit a good capsular reaction, whereas with others, such as albumin, less than $0.05 \%(\mathrm{w} / \mathrm{v})$ gave an indistinct reaction.

Of the proteins studied, only pepsin and trypsin gave a completely negative reaction with each of the capsulated organisms. Gelatin, bovine plasma albumin fraction no. $\mathrm{V}$ and egg albumin gave only a weak reaction with the Bacillus species. All the other non-basic proteins used reacted well with each of the capsulated micro-organisms.

A correlation between the isoelectric point of the proteins and the shifting of the reacting $\mathrm{pH}$ zone was observed with every micro-organism when using horse serum albumin, globulin or haemoglobin. The higher the isoelectric point of the protein, the higher the $\mathrm{pH}$ zone at which the optimal nonspecific capsular reaction occurred. The behaviour of some of the capsulated organisms towards lysozyme and protamine confirmed this observation. When a reaction occurred at all with these basic proteins, the reacting zone was extended up to weak alkaline reaction. A visible capsular reaction with basic proteins was found only with the Bacillus species. A peculiar feature of this reaction was the contraction of the bacterial capsule and the increased refractivity of the bacilli ( $\mathrm{Pl}$. 1, fig. 6). Only with the reaction of $\boldsymbol{B}$. anthracis with lysozyme could the capsule be demonstrated with almost normal appearance at $\mathrm{pH} 6$ and 7 , when the mixture was incubated several hours at room temperature (Pl. 1, fig. 7). The microscopic examination of $B$. megaterium and Bacillus $M$ had to be carried out at this $\mathrm{pH}$ very quickly with lysozyme, since these micro-organisms were dissolved very rapidly even at room temperature by a $0.05 \%(w / v)$ solution of purified lysozyme.

Another characteristic feature of the reaction with basic proteins and some of the bacteria was in the deformation of the bacterial cell. The strongest deformation was observed in the reaction of protamine on Bacillus $\boldsymbol{M}$. A visibly turbid suspension of these bacilli was killed completely when left for $3 \mathrm{hr}$. at room temperature, $\mathrm{pH} \mathrm{9,} \mathrm{with} 0.1-0.025 \%(\mathrm{w} / \mathrm{v})$ protamine solutions. A marked deformation of the bacterial bodies was observed under these circumstances down to $0.006 \%(\mathrm{w} / \mathrm{v})$ concentration of protamine. The deformation was very much less distinct with micro-organisms not belonging to the genus Bacillus.

The correlation of the $\mathrm{pH}$ zone of the non-specific reaction with the isoelectric point of the protein is best seen when the upper $\mathrm{pH}$ limit giving the strongest reaction is taken into consideration, as can be seen in Table 4. The pH values given in this table were established with electrometric measurements. The data given in Table 4 suggest that these proteins might form electrostatic compounds with the bacterial capsule at an inter-isoelectric $\mathrm{pH}$ value. The possibility of the occurrence of other binding forces cannot be excluded since some proteins, e.g. gelatin and ovalbumin, react differently with different capsules. Furthermore, casein, a protein which gives strong capsular reactions, reacts in a $\mathrm{pH}$ zone which corresponds rather to the globulin than to the albumin zone, despite the fact that its isoelectric point 
is identical with that of the albumin. Differences in the reaction towards different micro-organisms are most distinct when using basic proteins such as lysozyme and protamine.

Table 4. Upper $\mathrm{pH}$ limit of the capsular reaction with proteins of different isoelectric points

$\quad$ Protein
Albumin (horse serum)
Globulin (horse serum)
Haemoglobin
Lysozyme

$\begin{array}{cc}\text { Isoelectric } & \text { Cryptococcus } \\ \text { point } & \text { neoformans } \\ 4 \cdot 9 & 3 \cdot 0 \\ 5 \cdot 4 & 3 \cdot 2 \\ 6 \cdot 8 & 4 \cdot 4 \\ 9 \cdot 5 & c .6 \\ 10-12 & -\end{array}$

Bacillus
anthracis
$\mathbf{4 \cdot 4}$
$\mathbf{4 \cdot 6}$
$\mathbf{5 \cdot 4}$
c. 7
c. 8

Precipitation of the capsular substance with proteins at acid reaction

As pointed out previously, several proteins react at $\mathrm{pH}$ values on the acid side of their isoelectric points with the capsule of various micro-organisms, thereby making the capsule visible. Depending on the $\mathrm{pH}$ value in the reaction zone, the capsule appears either contracted, normal, or in some cases swollen. The reaction is sometimes homogeneous and extends to the whole depth of the capsule, as in the case of albumin ( $\mathrm{Pl}$. 1, fig. 2). In other cases, most frequently with casein and with haemoglobin and in lesser degree with globulin, the reaction appears usually as a precipitation at the surface of the capsule (Pl. 1, fig. 5; Pl. 2, fig. 18). Thus microscopic examination gives the impression that the essential feature of the reaction consists of a precipitation.

For the study of the precipitation of capsular substances with proteins Bacillus $\boldsymbol{M}$ was selected, because this organism, like $\boldsymbol{B}$. megaterium, contains polypeptide as well as polysaccharide in its capsule (Tomcsik \& Guex-Holzer, 1951, 1952). Three fractions were obtained from this organism: a D-glutamic acid polypeptide, a polysaccharide and a mucoprotein. The separation of the D-glutamic acid polypeptide from the polysaccharide was good. It was found that by mixing one volume each of polypeptide and albumin solution with eight volumes of acetate buffer $0.2 \%$ polypeptide had to be added to $1-2 \%$ albumin to obtain the largest amount of precipitate in a $\mathrm{pH}$ zone where the buffer solutions had values from $\mathrm{pH} 3 \cdot 3$ to $4 \cdot 2$. On increasing the $\mathrm{pH}$ of the buffer to $4 \cdot 4$, a turbidity but no precipitation occurred. Less concentrated polypeptide required also 5 to 10 times the quantity of albumin to produce the greatest turbidity; the precipitation was, however, not complete. The albumin used for the acid precipitation of the capsular substances was bovine plasma albumin fraction V. Protamine precipitated the polypeptide even at pH 7.

The purified polysaccharide was isolated by hot-water extraction from the capsulated bacilli; after hydrolysis it showed glucosamine and galactosamine, a trace of phosphorus, but no glutamic or uronic acids. This polysaccharide absorbed the antibodies from the homologous serum, revealing the characteristic capsular structure (Pl. 2, fig. 15) completely, but it gave no precipitation whatsoever with albumin at acid reactions. 
From the same organism, extracted with lysozyme, a mucoprotein was obtained which contained a serologically identical polysaccharide; it contained $7.8 \%$ nitrogen and $\mathbf{4 . 1} \%$ phosphorus. Uronic acid could not be demonstrated in this preparation. The mucoprotein did not contain any serologically active polypeptide, but it reacted with albumin in a $\mathrm{pH}$ zone slightly more acid than that of the polypeptide. A $0 \cdot 1 \%(\mathrm{w} / \mathrm{v})$ solution of the mucoprotein was precipitated with $0.5 \%(\mathrm{w} / \mathrm{v})$ solution of albumin in such a way that in the supernatant fluid neither the mucoprotein nor the albumin could be demonstrated. One analysis, in which higher concentrations of mucoprotein and albumin were used, will be described. Mucoprotein (100 mg.) was dissolved in acetate buffer $\mathrm{pH} 3.6$ (20 ml.). Albumin (250 mg.) dissolved in distilled water $(5 \mathrm{ml}$.) was added to it. An abundant precipitate appeared. The precipitate, redissolved at $\mathrm{pH} 7$, reacted with polysaccharide immune serum at a titre which suggested at most a $50 \%$ decrease of polysaccharide activity. The supernatant fluid after centrifugation was deproteinized by Sevag's method (1934). One part was hydrolysed by boiling with $2 \mathrm{~N}-\mathrm{HCl}$ for $5 \mathrm{hr}$. Only a trace of reducing substance could be shown after hydrolysis. A precipitin reaction carried out with the unhydrolysed supernatant fluid and polysaccharide antibody suggested an activity decreased to $1 / 100$ of the initial value.

The experiments cited here demonstrate that the polypeptide capsular substance, as well as the mucoprotein of the Bacillus $\boldsymbol{M}$, might produce insoluble salt-like compounds with proteins at a definite $\mathrm{pH}$ zone. By changing the $\mathrm{pH}$ value, a solution of the compound can easily be obtained. Thus the isolated capsular substance seems to behave in a similar way to the capsule itself. The purified polysaccharide of Bacillus $\boldsymbol{M}$ obtained by hot-water extraction, however, did not give a precipitation with albumin at acid reaction. This observation is concordant with our morphological findings, on the basis of the following considerations: (1) the non-specific capsular reaction with proteins (Pl. 2, figs. 11-13) does not reveal the morphologically very characteristic capsular structure; (2) the characteristic capsular structure (PI. 2, fig. 15) is revealed with an antibody which can be absorbed by purified polysaccharide, or by the muco-protein, but not by the D-glutamic acid polypeptide. At present we are unable to give a satisfactory explanation of why the lysozyme-extracted mucoprotein fraction reacts serologically in a similar way, and with the protein at acid reaction in a different way, as compared with the purified polysaccharide.

\section{DISCUSSION}

A non-specific capsular reaction had been demonstrated previously only with pneumococci. Löfström (1944) found that a 'capsular swelling' reaction of Diplococcus pneumoniae type XXVII could be elicited by neutral reaction with acute phase protein or with sera obtained from patients in the acute phase of lobar pneumonia or of other febrile illnesses. Calcium ion was essential for this reaction. He showed that the power of the acute phase serum to elicit the capsular reaction went parallel with its ability to give 
a pneumococcus C-polysaccharide precipitation discovered by Tillett \& Francis (1930).

A non-specific 'quellung' of several types of pneumococci at $\mathrm{pH} \mathbf{4 \cdot 0}$ by a variety of proteins was recognized for the first time by Jacox (1947). We assume that the principle underlying the 'capsular swelling reaction' of pneumococci described by Jacox is identical with the principle of the nonspecific capsular reaction described with various micro-organisms in this work; nevertheless, the following differences should be pointed out. Jacox found that the reaction was inhibited by even as low a concentration of sodium chloride as $0.02 \mathrm{M}$. We generally used $0.85 \%$ saline, corresponding to $0.145 \mathrm{M}$-sodium chloride, for the solution or dilution of the proteins and for the suspension of bacteria. We observed only in the case of Cryptococcus neoformans and the pneumococci that the capsular reaction with albumin was favoured when the $\mathrm{NaCl}$ concentration was decreased to $0.07 \mathrm{M}$. No such effect was observed, however, when using globulin, haemoglobin or other proteins. According to Jacox the non-specific capsular reaction occurs only with pneumococci. He found no reaction with Klebsiella pneumoniae, a mucoid Escherichia coli, or a mucoid Streptococcus haemolyticus, although acid agglutination was observed under these conditions. We could demonstrate the non-specific capsular reaction with all species of capsulated organisms studied, when using the appopriate $\mathrm{pH}$ range and with a number of different proteins.

Jacox described the non-specific capsular swelling of pneumococci at pH 4.0. He did not find a difference in the reaction $\mathrm{pH}$ zone with albumin or haemoglobin. By using $\mathrm{pH}$ intervals of at least $\mathbf{0 . 4}$ unit, as we did, it is easy to demonstrate that the reaction $\mathrm{pH}$ zones of albumin and of haemoglobin are different and also vary according to the organism tested. To demonstrate the difference between the reaction zones of such proteins as albumin and globulin, whose isoelectric points lay nearer to each other, $\mathrm{pH}$ differences of 0.2 should be used. The only protein which, in the work of Jacox, showed a higher pH than 4.0 for eliciting the capsular swelling of pneumococci, was a 3-phosphoglyceraldehyde dehydrogenase preparation. This protein has an isoelectric point at pH 6.55 according to Cori, Slein \& Cori (1948). This finding of Jacox fits well with our conception according to which the higher the isoelectric point of the protein, the higher the $\mathrm{pH}$ zone at which the non-specific capsular reaction occurs. It would be interesting to see whether the phenomenon observed by Löfström might not also be correlated with a high isoelectric point of the acute phase protein.

Jacox assumes that in the absence of ionized salts, the pneumococcus polysaccharide-protein gel becomes increasingly hydrophilic and therefore capable of enlarging to produce the 'quellung' reaction. We have shown that the non-specific capsular reaction at different $\mathrm{pH}$ zones depends as much on the isoelectric point of the proteins used as on the species of organism which produces polysaccharide or polypeptide capsular substance. We assume that the reacting portions of the molecules of the capsular polysaccharides or of the polypeptide are, for instance, uronic acids or D-glutamic acid, leading in an inter-isoelectric zone to the formation of salt-like compounds with proteins; 
the reaction is essentially a precipitation. The capsule itself may be contracted, of unchanged volume or, occasionally, swollen, depending on the $\mathrm{pH}$ value.

Unfortunately we were not able to carry out electrophoretic determinations on the bacteria used, to determine their isoelectric points. It may be assumed that the isoelectric point of the bacterial surface is lower when the optimal capsular reaction occurs at lower $\mathrm{pH}$. In consequence it should be lower with Cryptococcus neoformans and with Klebsiella pneumoniae than with Bacillus anthracis. We found no data in the literature about the isoelectric point of capsulated Cryptococcus neoformans or Bacillus anthracis. Harden \& Harris (1953) point out that misleading conclusions can result from attempts to interpret information regarding cellular isoelectric points from data obtained by the dye method. They found by micro-electrophoretic measurements that the isoelectric point of Klebsiella pneumoniae is $\mathbf{2 \cdot 4 8}$ and of Bacillus anthracis $3 \cdot 1$, i.e. the reverse of the values found by dye methods.

This work was carried out with the help of the Rockefeller Foundation.

\section{REFERENCES}

Alderton, G. \& Fevold, H. L. (1946). Direct crystallization of lysozyme from egg white and some crystalline salts of lysozyme. J. biol. Chem. 164, 1.

Ambrose, E. J. \& Hanby, W. E. (1949). Evidence of chain folding in a synthetic polypeptide and in keratin. Nature, Lond. $163,483$.

Bodon, G. \& Tomcsik, J. (1934). Effect of specific antibody on the capsule of anthrax bacilli. Proc. Soc. exp. Biol., N.Y. 32, 122.

Cori, G. T., Slein, M. W. \& Cori, C. F. (1948). Crystalline D-glyceraldehyde-3phosphate dehydrogenase from rabbit muscle. J. biol. Chem. 173, 605.

Drouhet, E., Segretain, G. \& Aubert, J. P. (1950). Polyoside capsulaire d'un champignon pathogène Torulopsis neoformans; relation avec la virulence. Ann. Inst. Pasteur, 79, 891.

Evans, E. E. \& Meru, J. W. (1951). A qualitative analysis of capsular polysaccharides from Cryptococcus neoformans by filter paper chromatography. Science, $114,10$.

Evans, E. E. \& Theriault, R. J. (1953). The antigenic composition of Cryptococcus neoformans. J. Bact. 65, 571.

Gradstone, G. P. \& Fildes, P. (1940). A simple culture medium for general use without meat extract or peptone. Brit. J. exp. Path. 21, 161.

Hanby, W. E. \& Rydon, H. N. (1946). The capsular substance of Bacillus anthracis. Biochem. J. 40, 297.

Hanby, W. E., Waley, S. G. \& Watson, J. (1948). Synthetic polyglutamic acid. Nature, Lond. 161, 132.

Harden, V. P. \& Harris, J. O. (1953). The isoelectric point of bacterial cells. J. Bact. 65, 198.

Housewright, R. D. \& Thorne, C. B. (1950). Synthesis of glutamic acid and glutamyl polypeptide by Bacillus anthracis. J. Bact. 60, 89.

Ivanovics, G. \& Bruckner, G. (1937). Chemische und immunologische Studien über den Mechanismus der Milzbrandinfektion und Immunität. Z. ImmunForsch. 90, 304.

Ivanovics, G. \& ERdös, L. (1937). Ein Beitrag zum Wesen der Kapselsubstanz des Milzbrandbazillus. Z. ImmunForsch. 90, 5.

$J_{\text {Acox, }}$ R. F. (1947). A new method for the production of non-specific capsular swelling of the pneumococcus. Proc. Soc. exp. Biol., N.Y. 66, 635. 
Kolmer, J. A. (1924). Infection, Immunity and Biologic Therapy. Philadelphia: W. B. Saunders Company.

Löfström, G. (1944). Comparison between the reactions of acute phase serum with pneumococcus C-polysaccharide and with pneumococcus Type 27. Brit. J. exp. Path. 25, 21.

NaKamura, O. (1923). Über Lysozymwirkungen. Z. ImmunForsch. 38, 425.

Neill, J. M., Castillo, C. G., Smith, R. H. \& Kapros, Ch. E. (1949). Capsular reactions and soluble antigens of Torula histolytica and of Sporotrichum schenkii. J. exp. Med. 89, 93.

Sahyun, M. (1944). Outline of the Amino-Acids and Proteins. New York: Reinhold.

Sevag, M. G. (1934). Eine neue physikalische Enteiweissungsmethode zur Darstellung biologisch wirksamer Substanzen. Biochem. Z. 273, 419. [Or: Sevag, M. G. (1951). Immuno-Catalysis. Springfield, Illinois, U.S.A.: Charles C. Thomas.]

Stacey, M. (1946). The Chemistry of Mucopolysaccharides and Muco-proteins in Advances in Carbohydrate Chemistry. New York, N.Y.: Academic Press Inc. Publishers.

Teorell, T. \& Stenhagen, E. (1938). Ein Universalpuffer für den pH-Bereich 2, 0 bis 12,0. Biochem. Z. 299, 417.

Tillett, W. S. \& Francis, Th. (1930). Serological reactions in pneumonia with a non-protein somatic fraction of pneumococcus. J. exp. Med. 52, 561 .

Tomcsik, J. (1950). Über eine bewegliche Mutante des B. anthracis. Schrveiz. $Z$. Path. 13, 616.

Tomcsik, J. (1951). Complex structure of the bacterial capsule in the genus Bacillus. Experientia, 7, 459.

Tomcsik, J. \& Guex-Holzer, S. (1951). Anthrax-Polypeptid und andere speziesspezifische Substanzen der Kapsel in der Bazillus-Gruppe. Schreiz. Z. Path. $14,515$.

Tomcsik, J. \& Guex-Holzer, S. (1952). Änderung der Struktur der Bakterienzelle im Verlauf der Lysozym-Einwirkung. Schweiz. Z. Path. 15, 518.

Tomcsik, J. \& Szongotт, H. (1933). Über ein spezifisches Protein der Kapsel des Milzbrandbazillus. Z. ImmunForsch. 77, 86.

\section{EXPLANATION OF PLATES}

(All photomicrographs at $\times 3000$, phase-contrast microscope.)

Plate 1

Fig. 1. B. anthracis, grown in $20 \% \mathrm{CO}_{2}$, bovine plasma albumin fraction $\mathrm{V} .0 \cdot 025 \%$, $1 / 1280 \mathrm{~N}-\mathrm{HCl}$; capsule invisible.

Fig. 2. B. anthracis $\left(20 \% \mathrm{CO}_{2}\right)$ and Klebsiella pneumoniae, type $\mathrm{B}$; bovine plasma albumin fraction V. $0.025 \%, 1 / 640 \mathrm{~N}-\mathrm{HCl}$. B. anthracis: homogeneous capsule; $K$. pneumoniae: capsule invisible.

Fig. 3. B. anthracis, $20 \% \mathrm{CO}_{2}, \mathrm{~K}$. pneumoniae, type B, egg globulin $0 \cdot 2 \%, 1 / 320 \mathrm{~N}-\mathrm{HCl}$.

$B$. anthracis: homogeneous capsule; $K$. pneumoniae: capsule with secondary swelling.

Fig. 4. B. anthracis, $20 \% \mathrm{CO}_{2}, K$. pneumoniae, type $\mathrm{B}$, bovine serum $1: 80,1 / 240 \mathrm{~N}-\mathrm{HCl}$. $B$. anthracis: capsule contracted to a slight degree; $K$. pneumoniae: no capsule swelling.

Fig. 5. B. anthracis, $25 \% \mathrm{CO}_{2}$, casein $0 \cdot 05 \%, 1 / 640 \mathrm{~N}-\mathrm{HCl}$. Capsule reaction: marginal precipitation. Voluminous casein precipitate.

Fig. 6. B. anthracis, $25 \% \mathrm{CO}_{2}$, lysozyme (Mann) $0 \cdot 2 \%, \mathrm{pH}$ of the buffer solution $5 \cdot 2$. Capsule: strong retraction; bacilli: light scattering.

Fig. 7. B. anthracis, $20 \% \mathrm{CO}_{2}$, lysozyme (Alderton) $0 \cdot 2 \%, \mathrm{pH}$ of the buffer solution $9 \cdot 5$. Capsule: homogeneous; bacilli: lysozyme effect.

Fig. 8. B. megaterium, horse serum $1: 8, \mathrm{pH} \mathrm{4} \cdot 1$. Capsule: normal, no swelling.

Fig. 9. B. megaterium, bovine serum $1: 8, \mathrm{pH} \mathrm{4.4}$. Capsule: large swelling and deformation, owing to the lysozyme content of the serum.

Fig. 10. B. subtilis, 5 hr. agar-culture, human serum $1: 20, \mathrm{pH}$ of the buffer solution $3 \cdot 6$. Capsule: very abundant like in indian ink preparation. 
Journal of General Microbiology, Vol. 10, No. 1
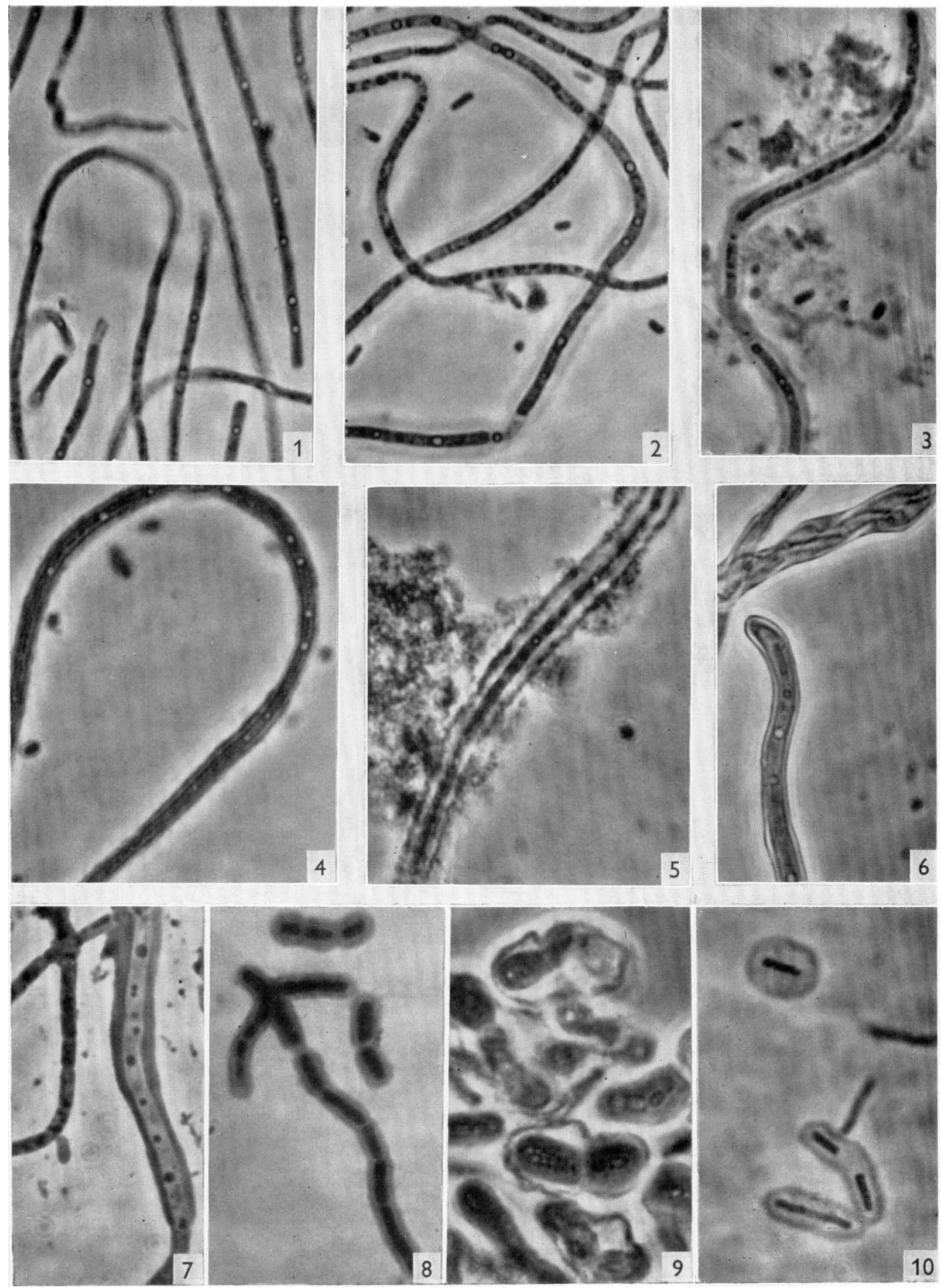

J. Tomcsik \& S. Guex-Holzer-Reaction of bacterial capsules with proteins. Plate 1 
Journal of General Microbiology, Vol. 10, No. 1
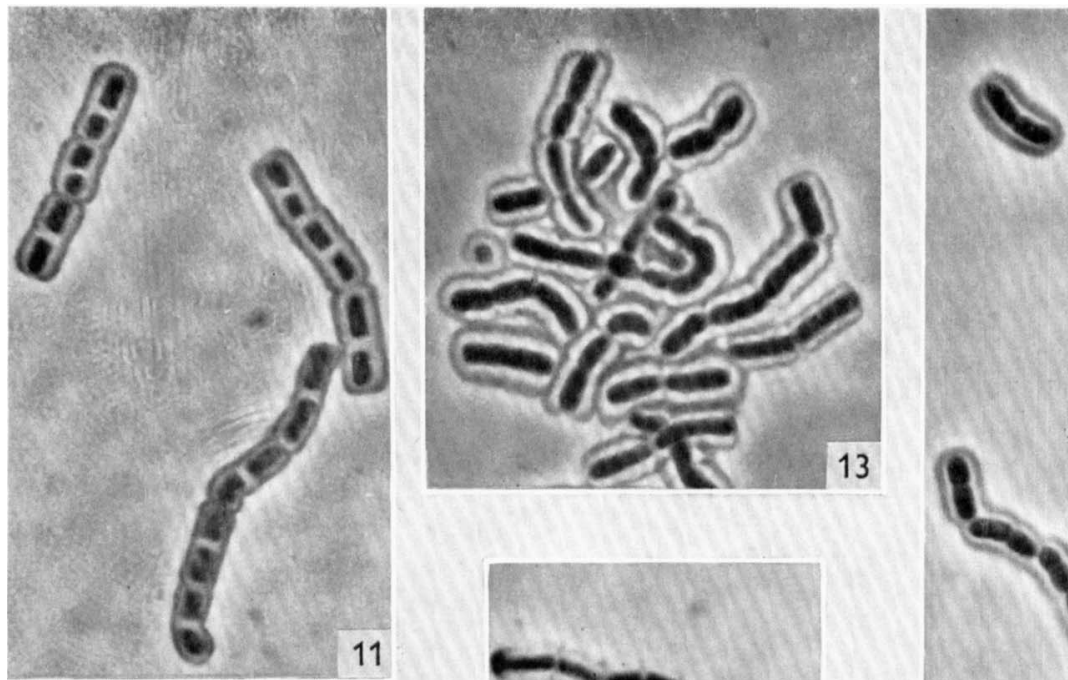

13
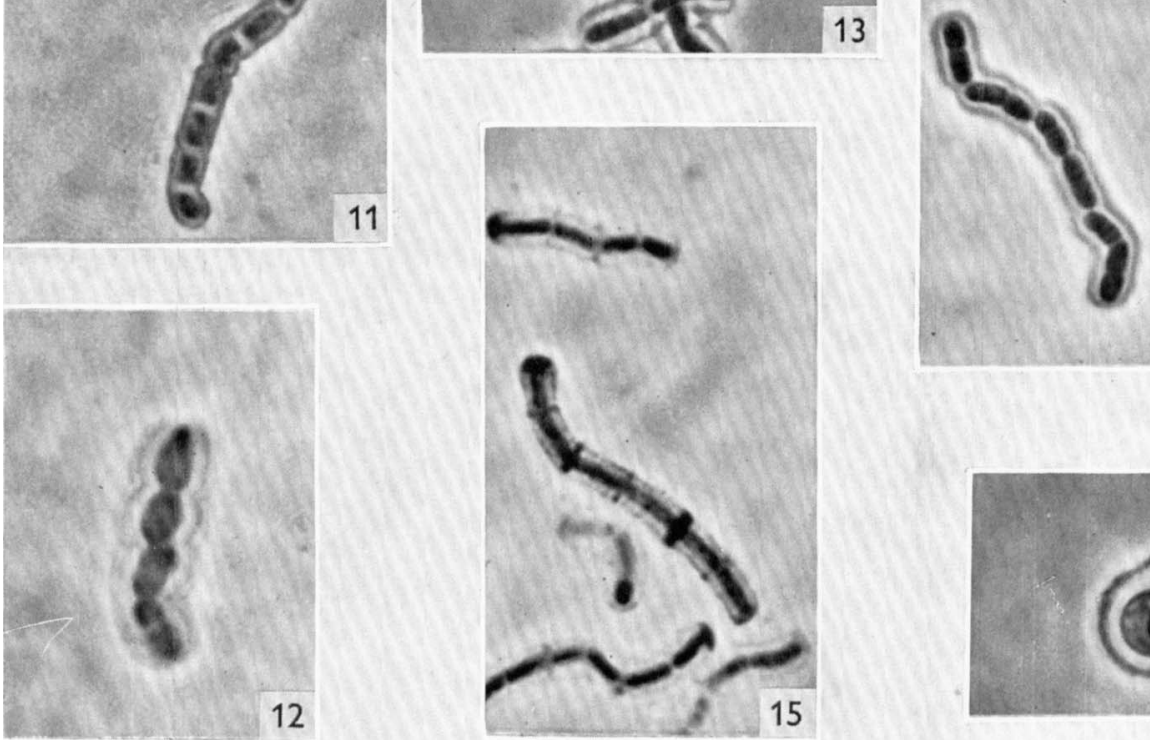

12
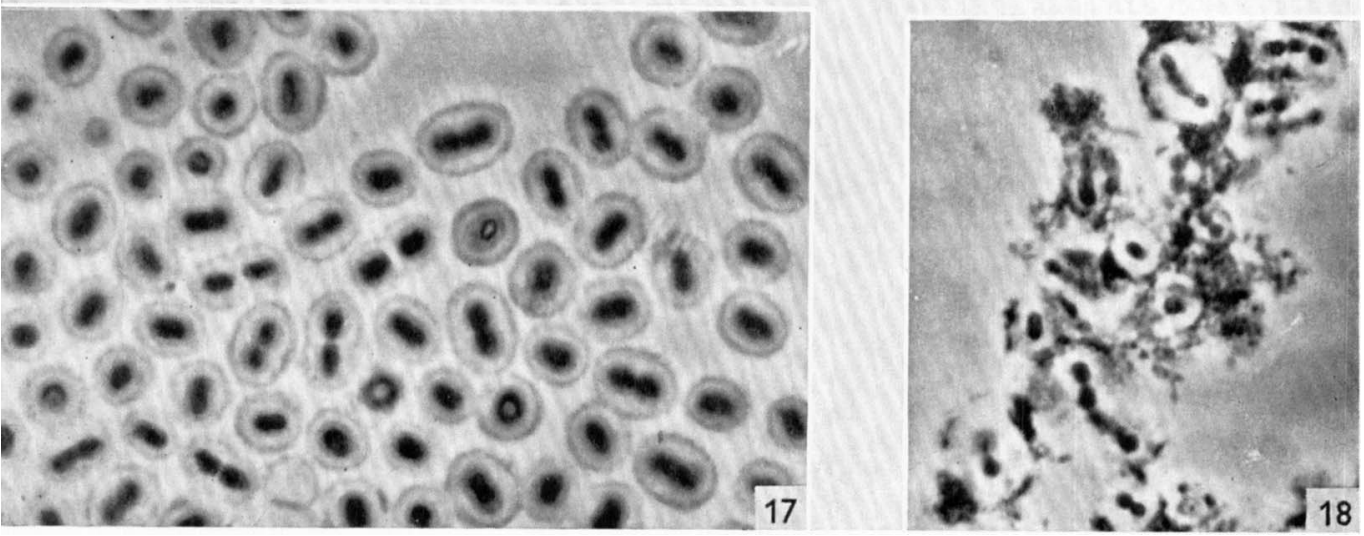

J. 'Tomcsik \& S. Guex-Holzer-Reaction of bacterial capsules with prothins. Plate 2 


\section{Plate 2}

Fig. 11. Bacillus $M$, bovine serum $1: 20,1 / 400 \mathrm{~N}-\mathrm{HCl}$. Capsule with polar depression; bacilli with slight lysozyme effect ( $1 \mathrm{hr}$. at room temperature).

Fig. 12. As in Fig. 11, after a few hours at room temperature. Circular structure (it occurs rarely) and polar depression of the capsule, lysozyme deformation of the bacilli.

Fig. 13. Bacillus $M$, bovine serum $1: 20,1 / 300 \mathrm{~N}-\mathrm{HCl}$. Agglutinated bacteria, some of them show a polar depression of the capsule.

Fig. 14. Bacillus $M$ and $D$-glutamic acid polypeptide antibody (undiluted) at neutral reaction. The polar portion of the capsule is thin.

Fig. 15. Bacillus $M$ and homologous serum, containing polysaccharide antibody (undiluted). Capsule with very marked polar bodies and transverse septa. After absorption of the serum with the purified Bacillus $M$ polysaccharide this capsular reaction cannot be elicited. Polypeptide absorption does not alter this reaction.

Fig. 16. Cryptococcus neoformans, egg-white $1: 40, \mathrm{pH}$ of the buffer solution $2 \cdot 0$. The capsule shows the same size as in indian ink preparation.

Fig. 17. Klebsiella pneumoniae, type A, human serum $1: 20, \mathrm{pH}$ of the buffer solution $3 \cdot 2$. Size of the capsule as in wet indian ink preparation.

Fig. 18. Pneumococcus type III, haemoglobin $0.05 \%, \mathrm{pH}$ of the buffer solution $3 \cdot 6$. Capsular swelling compared to indian ink preparation is apparent. Precipitation around the capsules. 